\title{
A vezetési stílus vizsgálata és összehasonlítása két multinacionális vállalat esetében
}

\author{
A. MATKÓ, T. TAKÁCS \\ University of Debrecen, andim@eng.unideb.hu \\ University of Debrecen, takacst@eng.unideb.hu
}

Abstract. A vezetés a 21. században az élessé vált gazdasági válságban való versenyképesség megtartásában és megörzésében kulcsfontosságú szerepet játszik. Ehhez hozzájárul az a tény is, hogy a vezetés nem csak alakítója, hanem része is annak a viszonynak, hogy a vevői szükségletek és a szervezet követelményei úgy kerüljenek összhangba, hogy mind a két fél elérje a céljait. Egy vezető feladata, hogy összekapcsolja az egyéni és a szervezeti célokat, elérve ezáltal a legjobb szervezeti teljesítményt és a legnagyobb munkavállalói elégedettséget. Ehhez viszont szükséges felismernie azt, hogy a vállalati kultúra és az egyes munkavállalók milyen vezetési stílus alkalmazását követelik meg. Kutatásunk célja, hogy két multinacionális vállalat esetében egy vezetési stílust mérô kérdőív segitségével feltárjuk a sikeres vezetés ismérveit és összehasonlítsuk a kapott eredményeket.

\section{Bevezetés}

A vállalatok esetében a kialakult gazdasági helyzetben meghatározó szempont a versenyképesség. A folyamatosan változó piaci környezet és a növekvő igények miatt a piaci verseny egyre szorosabbá válik. A piaci pozíció megőrzéséhez nélkülözhetetlen a vezetés. Ahhoz, hogy egy szervezet gyorsan tudjon reagálni a gazdaság változásaira megfelelő vezetésre van szüksége, így a gyors és határozott intézkedések segítségével alkalmazkodik a környezeti változásokhoz. Ebből kifolyólag nagyon fontos, hogy a vezetők milyen vezetési stílussal rendelkeznek, és fontos annak a vizsgálata is, hogy az egyes vállalatok esetében specifikusan mely stílus az, amely hozzájárul az eredményes vezetéshez.

A vezetés fontos szerepe, hogy a szervezet profitorientáltságát megőrizze amellett, hogy a hatékonyságot növeli, és a kiadásokat csökkenti, ugyanis ez a módja a piacon való stabil fennmaradásnak. A vezetők a külső körülményekhez való alkalmazkodás gyorsaságában is szerepet játszanak. Megfogalmazzák a vállalat jövőképét, értékeket és irányelveket határoznak meg a szervezetben dolgozók felé. A célok és célkitűzések képessé teszik a szervezetet a rövid és hosszú távú eredmények eléréséhez.

Egy vezető feladata, hogy összekapcsolja az egyéni és a szervezeti célokat, elérve ezáltal a legjobb szervezeti teljesítményt és a legnagyobb munkavállalói elégedettséget. Ehhez viszont szükséges felismernie azt, hogy a vállalati kultúra és az egyes munkavállalók milyen vezetési stílus alkalmazását követelik meg.

Kutatásunk célja, hogy két multinacionális vállalat esetében egy vezetési stílust mérő kérdőív segítségével feltárjuk a sikeres vezetés ismérveit és összehasonlítsuk a kapott eredményeket. 
Vizsgálatunk célcsoportja a vállalatok vezetői. Annak érdekében, hogy árnyaltabb képet kaphassunk a vezetői stílusokról különböző szinteken lévő vezetőket vizsgálunk meg.

A kapott eredményeket felhasználva és az azokból levont következtetések segítségével további célunk, hogy két, hosszú idő óta sikeres vállalat példáján keresztül megvizsgáljuk az eredményes vezetés és ezáltal a versenyképesség kulcstényezőit.

\section{A vezetés jelentősége a 21 . században}

A vezetés egy rendkívül összetett tudományág, amely sikereses alkalmazására a szervezetnek szükségük van ahhoz, hogy elérjék a kitűzött céljaikat. Éppen ezért a szervezetek vezetésének tudománya egyre nagyobb jelentőséggel bír, és egyre jobban felértékelődik korunkban. Ezt mi sem bizonyítja jobban, mint hogy a 21. század tudományos irodalmai már a társadalomtudományok egyik önálló részeként azonosítják. [2.]

Ennek a fejlődésnek több oka is van, melyek közül az egyik a gazdasághoz köthető. A vezetés kulcsfontosságú szerepe, hogy növelje a termelékenységet az erőforrások optimális összehangolásával, és ez által kielégítse a társadalom anyagi szükségleteit. A vevői igények manapság egyre szélesebbek, nagyobbak, folyamatosan változnak és növekednek. Ahhoz, hogy egy vállalat az elvárásoknak továbbra is eleget tudjon tenni a vezetési tevékenység átgondolására, megreformálására van szükség. [2.]

A másik ok társadalmi eredetű. A vezetés formálja az egy csoportban, egy közös célért dolgozó emberek társadalmi kapcsolatait, és fejleszti tudásukat, közösségi szellemüket. A világ és vele együtt a társadalmak, egyének egyre gyorsabban fejlődnek, és a változással a vezetés tudományának is lépést kell tartania ahhoz, hogy a funkcióinak továbbra is eleget tegyen. [2.]

A harmadik ok pedig a vállalatokkal kapcsolatos. A szervezetek célja napjainkban a minél nagyobb profit szerzése, a hatékonyság növelése, a piacon való stabil elhelyezkedés és természetesen a hosszú távú fennmaradás. Mindezekhez elengedhetetlen a vállalat összes funkciójának eredményes működése. A szerepekkel szervesen összekapcsolódik a vezetés, amely minden funkcióban jelentőséggel bír, és egyiktől sem választható külön. [2.]

Levonhatjuk azt a következtetést, hogy többé már nem gondolkozhatunk úgy a vezetésről, mint eddig. Nem tudunk sikerre vinni egy vállalatot a hierarchikus, merev, rugalmatlan, szűk látókörű múltbéli módszerekkel, szemlélettel. Változtatásokra van szükség.

\subsection{A vezetés szerepe a szervezeti célok megvalósításában}

A vezetés egyik kulcsfontosságú szerepe oly módon nyilvánul meg, hogy az erőforrások optimális összehangolásával növeli a termelékenységet, ezáltal kielégítve a társadalmi igényeket. A vezetés másik fontos szerepe a szervezet profitorientáltságának megőrizése a hatékonyság növelése és a kiadások csökkentése révén, mely biztosítja a piaci stabilitást. A ma vezetőjének fel kell ismernie, hogy csoportban kell dolgozni a közös célok és érdekek figyelembe vételével, amelynek kulcsfontosságú tényezője az ismert és elérhető célok megvalósítása. 
A vezetőknek gondoskodniuk kell arról, hogy minden tevékenység elvégzése és minden munkakör ellátására megfelelően képzett személy kerüljön. A vezetőknek folyamatosan utasítást, útmutatást kell adniuk a beosztottaknak, annak érdekében, hogy a követelményeknek megfelelően eleget tudjanak tenni a kötelességeiknek. A vezetés részét képezi a döntéshozatal, döntés az információk figyelembe vételével egy cselekvéssorozat megtételéről. A motiváció során a vezetők munkára ösztönzik a beosztottakat szükségleteik és igényeik figyelembe vételével, illetve ezek tükrében személyes megbeszéléseket folytatnak velük a munka magasabb színvonalú, hatékony elvégzése érdekében.

Ternovszky szerint a vezetést tulajdonképpen úgy határozhatjuk meg, mint olyan tevékenységet, amely egyének vagy csoportok viselkedésének befolyásolására irányul. A definícióból kitűnik, hogy a vezetés középpontjában az ember áll. E szemlélet alapján a vezetés egyik legfontosabb összetevője az emberekkel való bánásmód, amelyhez szorosan hozzákapcsolódnak a vezető humán és társadalmi ismeretekben való jártassága. [7.]

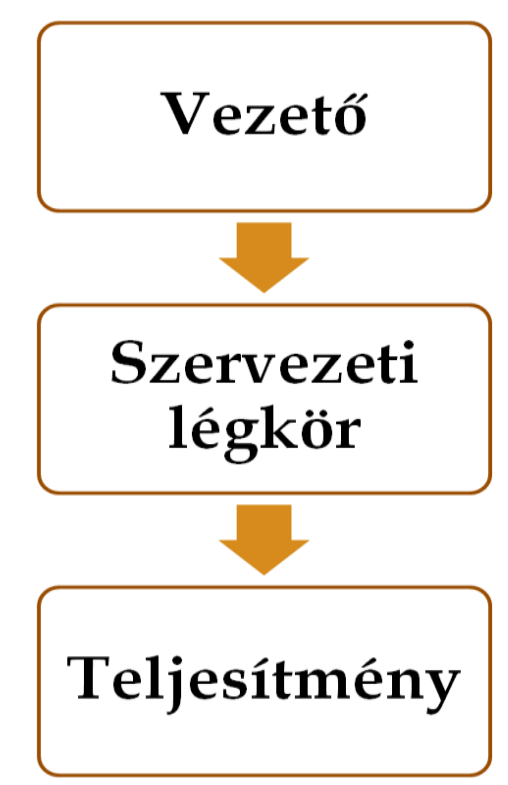

1. ábra: A szervezeti légkör és a teljesítmény kapcsolata

(Forrás: [3.])

A vezetés célja, hogy összhangba kerüljenek a szervezet körülményei és az emberi szükségletek, ezáltal mindkét fél elérje a céljait. Ez egy nagyon összetett és bonyolult feladat, amely sikeres megvalósítása attól függ, hogy a vezető milyen kompetenciákkal rendelkezik, és azokat hogyan tudja felhasználni és alkalmazni. [3.]

\section{Hersey és Blanchard elmélete}

A leadership elméletek sajátossága abban rejlik, hogy egy vezető hogyan tudja a saját alkalmazottainak értékeit, szükségleteit felismerni, összekapcsolni és hatékonyan mozgósítani. Az alkalmazott vezetési stílus több tényezőtől függ: a vezető személyiségétől, a beosztottak és a szervezet, a környezet viselkedésétől, a vezetőtől, a csoporttól, a szervezet céljaitól és szükségletei. 
A sikeresség alapja a vezető tudatos erőfeszítése, illetve a változó helyzetekhez való alkalmazkodási képesség mozgósításnak képessége, vagyis a vezető tartja kezében a problémákra a megoldás kulcsát, abban a tekintetben, hogy mennyire képes az adott helyzet, szituáció felmérésére, diagnosztizálására és a kialakult helyzethez / helyzetekhez hogyan tudja igazítani a stílusát, viselkedését. A vezetés akkor hatékony, ha minden szempontból megfelel annak a szituációnak, amelyben alkalmazni kell. [1.]

A helyzethez igazított vezetés alapelemei:

- feladatra figyelés

- kapcsolatra figyelés

- a munkatárs és a feladat jellemzői

- a vezető igényei. [4.]

Az egyes stílusokhoz jellemző vezetői viselkedéseket Hersey és Blanchard fogalmazták meg (Ford, 1995). Elméletük szerint a vezetőknek váltogatni kell az egyes vezetői stílusok között, azonban a vezető stílusát meghatározza a beosztottak érettsége. A beosztottak értettségének növekedésével a kapcsolatorientált stílusok eredményesebbek. Az érettség egy adott szintje felett engedni kell, hogy a beosztottak akarata érvényesüljön. Ezért a modell független változója a követők személyiségének érettsége. A modell szerint négy egymástól jól elkülöníthető vezetői stílust különböztetünk meg (2. ábra).

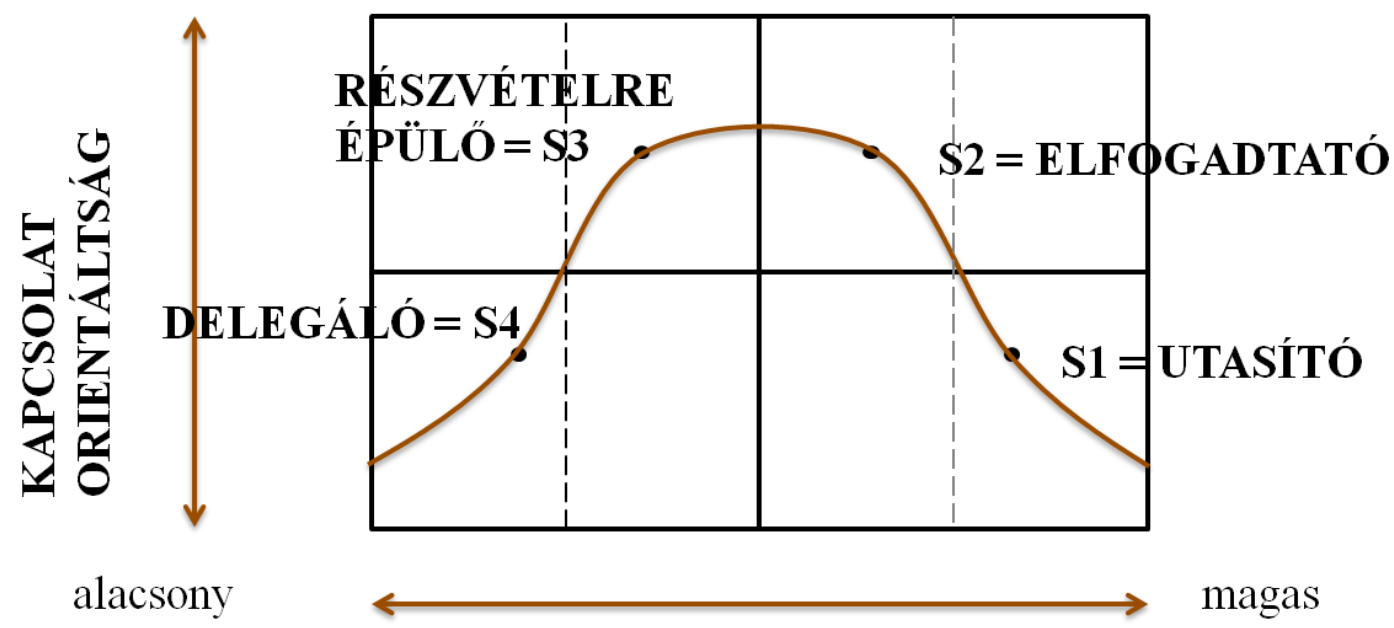

FELADAT ORIENTÁLTSÁG

2. ábra: A szervezeti légkör és a teljesítmény kapcsolata

(Forrás: [6.])

Az ábra alapján láthatjuk, hogy Hersey és Blanchard négy vezetői típust különít el a kapcsolat orientáltságának szintje szerint, modelljük a feladat- és a kapcsolatorientált magatartásokat tükrözi.

S1. Utasító vezetés: Erős feladat-, gyenge kapcsolatorientáltság jellemzi a vezetőt. A vezető tudja mit akar, és világosan el is mondja a beosztottainak. Világos egyértelmű utasítások jellemzik, erős 
szabályozó és ellenőrző funkció. Gyakran például erre van szükség az újonnan belépő dolgozók esetében

S2. Elfogadtató vezetés (Coaching): Erős feladat- és kapcsolatorientáltság jellemzi a vezetőt. A vezető részletesen elmagyarázza a teendőket. Kétirányú kommunikációra és motivációra épülve igyekszik bizalmat ébreszteni a dolgozókban, de a döntések felelősségét, az ellenőrzést a vezető nem adja ki a kezei közül. A humánus hozzáállás, a csoportmunka, a szabványok tudatosítása a munkacsoport szempontjainak mérlegelése és a folyamatok szabályozása jellemzi ezt a vezetői stílust. Ez a stílus a leginkább még nem tapasztalt kezdő dolgozók számára a megfelelő.

S3. Bevonó vezetés (szupportív): Gyenge feladat-, erős kapcsolatorientáltság jellemzi a vezetőt. Ezen stílus esetén a vezető és a csapat együtt dönt. A vezető ebben az esetben azon van, hogy a munkába és a döntéshozatalba mindenki be legyen vonva és a munkatársak támogatva érezzék magukat.

S4. Delegáló vezetés: Gyenge feladat- és kapcsolatorientáltság jellemzi a vezetőt. A vezető önállóságot ad a beosztottainak. Célokat a munkatársak határozzák meg és a problémákat szintén ők oldják meg és mindezt a vezető egyfajta támogatásával teszik. [5.]

A modell független változójának az érettséget tekintik, melynek négy szintjét különböztetjük meg a beosztottak szemszögéből (3. ábra).

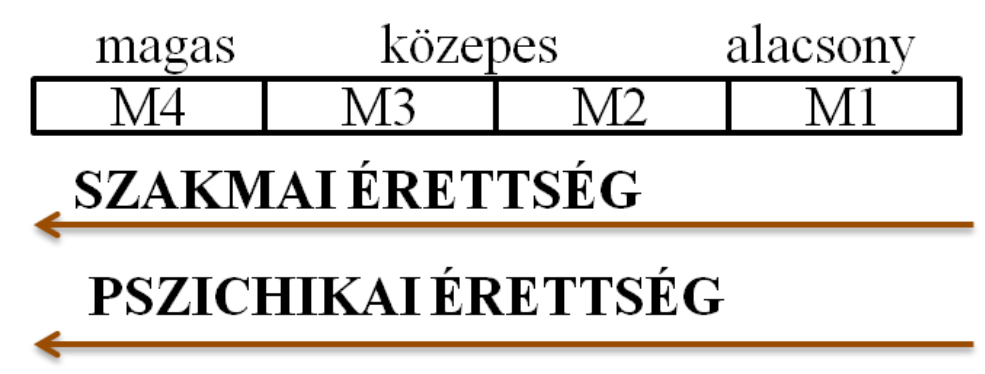

\section{3. ábra: Beosztottak érettsége}

(Forrás: [6.])

M1: A beosztottak nem képesek, és nem hajlandóak felelősséget vállalni, mert sem képességeik, sem önbizalmuk nem teszi lehetővé.

M2: A beosztottak hajlandóak lennének, de nem képesek elvégezni a szükséges feladatokat. Ugyan kellően motiváltak, de pillanatnyilag hiányoznak a megfelelő képességeik.

M3: A beosztottak képesek lennének elvégezni a feladatokat, de nem hajlandóak megtenni azt, amit a vezető kér tőlük.

M4: A beosztottak képesek és hajlandóak is megtenni azt, amit elvárnak tőlük.

Hersey és Blanchard szituációs leadership modellje szerint a legkevésbé érett beosztottak (M1) egyértelmű és konkrét irányítást várnak a vezetőtől. Az (M2) szint képességhiányát a vezetői oldalról erőteljes irányítás és az ezt pszichológiailag kompenzáló, ugyancsak erőteljes kapcsolatorientáció ellensúlyozza. Az (M3) szint jellemzője a Motiváció hiánya, amit támogató részvételi stílussal 
kezelhetünk. Az (M4) szinten elmondható, hogy a vezető „hátradőlhet” mert beosztottai kellően motiváltak, feladatorientáltak és képesek és készek felelősséget vállalni. [5.]

\section{A vezetési stílus vizsgálata és összehasonlítása két multinacionális vállalat esetében}

Kutatásunk célja, hogy két multinacionális vállalat esetében egy vezetési stílust mérő kérdőív segítségével feltárjuk a sikeres vezetés ismérveit és összehasonlítsuk a kapott eredményeket. Vizsgálatunk célcsoportja a vállalatok vezetői. Annak érdekében, hogy árnyaltabb képet kaphassunk a vezetői stílusokról különböző szinteken lévő vezetőket vizsgálunk meg, így az alsóvezetőket, középvezetőket és felsővezetőket mindkét vállalat esetében. A vizsgálatunk eszköze önkitöltős kérdőív volt, amelyet mindkét vállalatban az összes vezető kitöltött.

Mindkét bázisvállalat magyarországi multinacionális cég, amelyek anyavállalat külföldi tulajdonú, mindkét cég több mint 1000 embert alkalmaz és fő tevékenységi körük a gyártás és exportálás.

\subsection{Alsóvezetők vizsgálata}

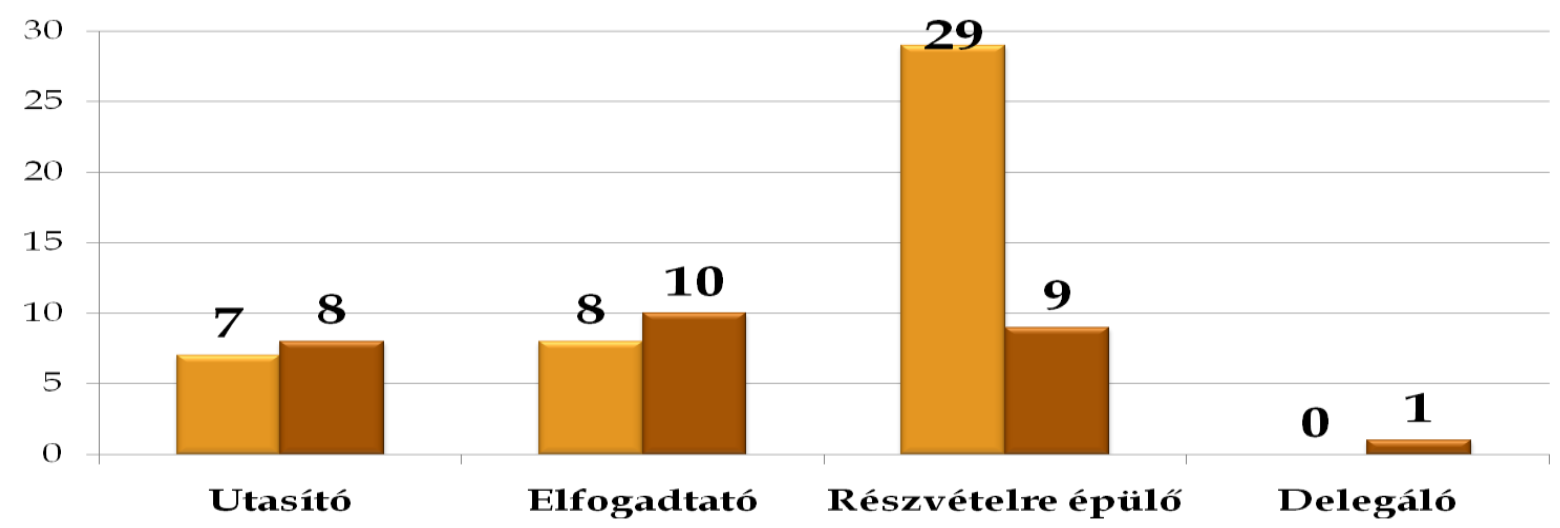

4. ábra: Alsóvezetők vezetési stílusa

(Forrás: Saját adatbázis alapján)

A 4. ábra szemlélteti az alsóvezetők vezetési stílusát. Amint a kapott eredmények is mutatják az egyik vállalat esetében a megvizsgált 32 fő közül 29-re jellemző a részvételre épülő vezetési stílus alkalmazása, melynek oka, hogy a vállalati kultúrából adódóan is az alkalmazottak bevonása a döntéshozatalba, illetve az egyes folyamatokba rendkívül meghatározó. 8 fő alkalmaz elfogadató stílust, illetve 7 fő utasító stílust. Utóbbinak az oka, hogy az alsószintű vezetők az operátorokat irányítják, amely esetben sokszor találkoznak nehezen motiválható alkalmazottakkal, így ennek a stílusnak a használata is megjelenik ezen a vezetői szinten. Erre a vállalatra ezen a vezetői szinten nem jellemző a delegáló vezetési stílus használata. A másik vállalat esetében nagyobb szórás mutatkozik meg a kapott eredményekben, a vizsgált 28 fő közül majdnem ugyanannyian alkalmazzák az utasító, az elfogadtató és a részvételre épülő stílust, illetve egy fő esetében megjelenik a delegálás is. Ez azt 
mutatja, hogy az ezen a szinten lévő vezetők esetében a feladat- és kapcsolatorientáltság szintje nagyon eltérő.

\subsection{Középvezetők vizsgálata}

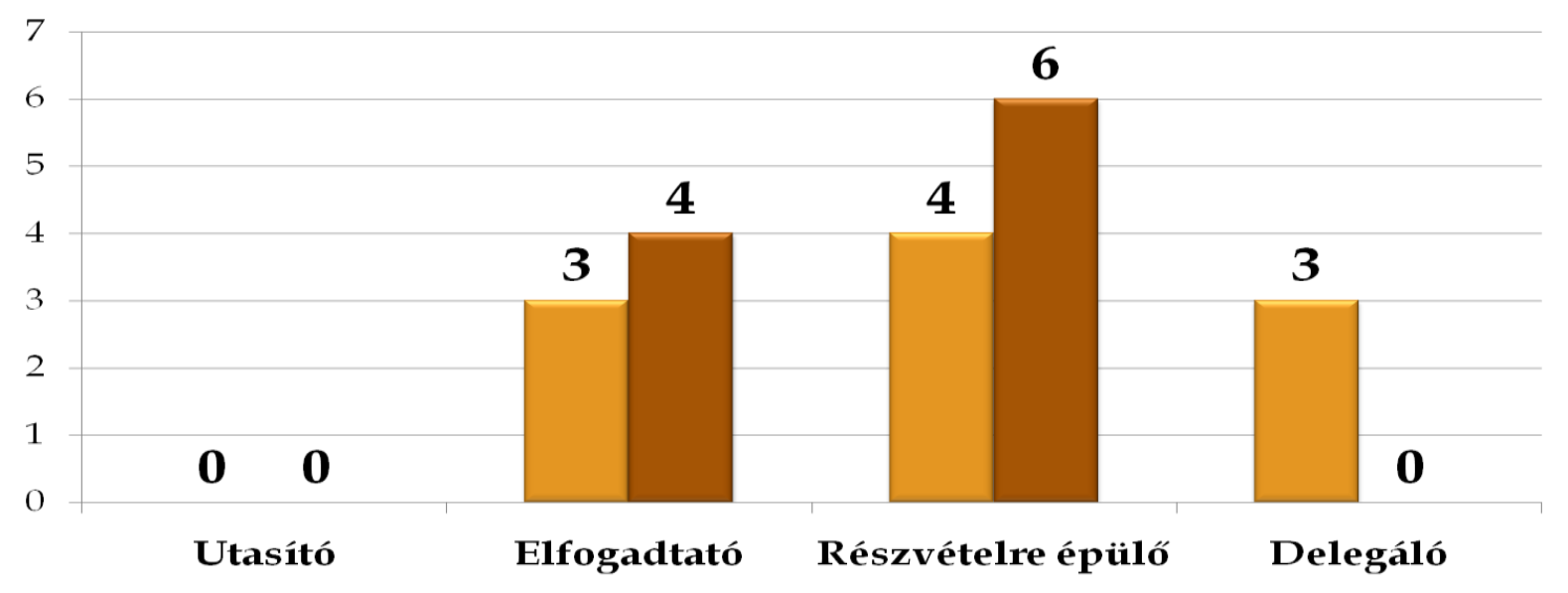

5. ábra: Középvezetők vezetési stílusa

(Forrás: Saját adatbázis alapján)

Az 5. ábra a középvezetőkre jellemző vezetési stílusokat mutatja be. A kapott eredmények azt mutatják, hogy az utasító stílus ezen a szinten egyik vizsgált vállalatra sem jellemző. Ennek fő oka, hogy a középvezetői réteg főként az alsó szintű vezetőknek ad utasításokat, így ennek a stílusnak a használata nem indokolt. A vizsgált 7-7 főre mindkét vállalat esetén a legjellemzőbb az elfogadtató és a részvételre épülő vezetési stílus, ami azt jelenti, hogy vagy a feladat- vagy a kapcsolatorientáltság szintje magas, a vezetőket világos utasítások, kétirányú kommunikáció és motiváció jellemzi. Az egyik vállalat esetében 3 főnél megjelenik a delegáló stílus is.

\subsection{Felsővezetők vizsgálata}

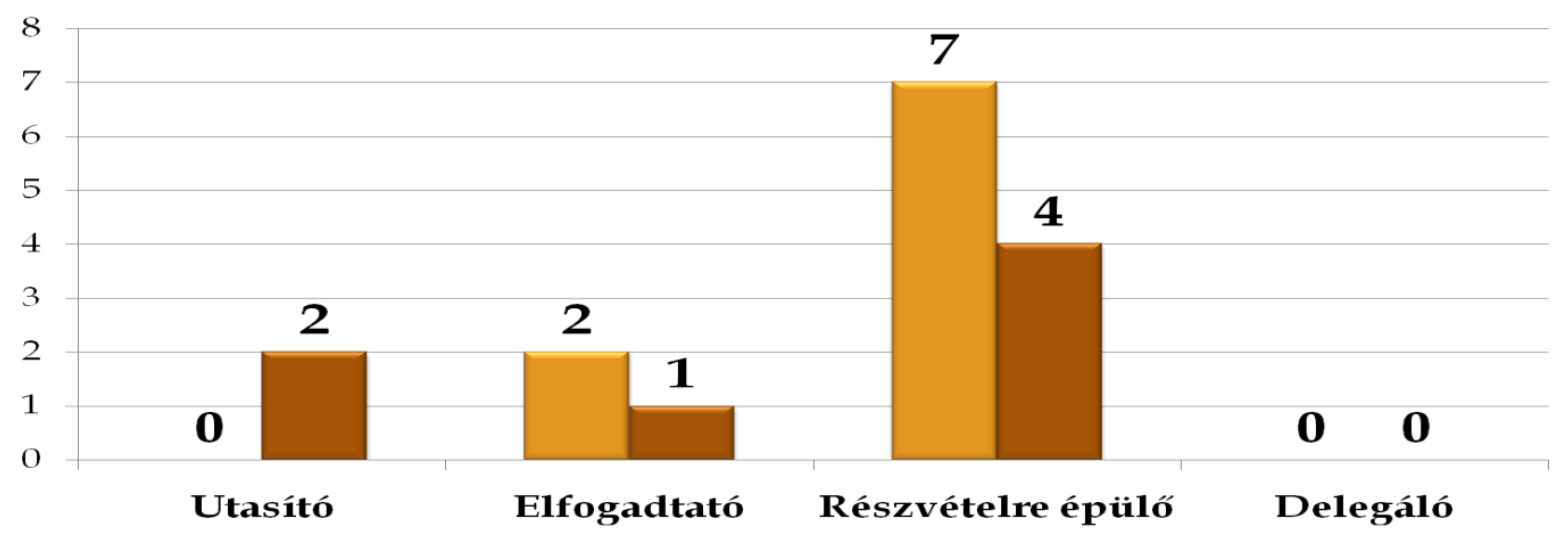

6. ábra: Felsővezetők vezetési stílusa

(Forrás: Saját adatbázis alapján) 
A 6. ábrán a felsővezetőkre jellemző vezetési stílusokat az általunk vizsgált két vállalat esetében, melyeknek 7-7 fôt vizsgáltunk meg a középvezetői réteghez hasonlóan. A delegáló stílus egyik vállalat felsővezetőire sem jellemző. Ez azt mutatja, hogy a vezetők nem alkalmazzák a delegálás módszerét. A részvételre épülő stílus az egyik vállalatnál dominánsan jelenik meg, a vizsgált 7 főből 6-ra jellemző, amely az alsóvezetőkhöz hasonlóan azt mutatja, hogy a vállalat esetében nagyon fontos szerepe van a dolgozók bevonásának, a fontosabb, felsővezetői döntések esetében is. 2 fő esetében az elfogadtató vezetési stílus használata is megjelenik. A másik vállalatnál szintén a bevonás jelenik meg legnagyobb számban (4 fő), illetve az elfogadató stílus is jellemez 1 főt. Ebben az esetben 2 fő felsővezető esetében megjelenik az utasító stílus használata is, amely a vállalati kultúrával magyarázható.

\section{Javaslatok}

Az általános vezetői tréningek az időgazdálkodásban, a vezetői kompetenciák fejlesztésében és a vezető stílus kialakításában nyújtanak segítséget. Javasolnánk mindkét vállalat részére az ilyen témájú oktatások megismétlését évenkénti gyakorisággal minden vezetői szinten.

A workshopok alkalmasak a vezetéssel kapcsolatos új módszerek elsajátítására. A workshop fogalmát használják a kommunikációs műfajok keretében megbeszélés elnevezéssel, illetve a forma tartalmának megfelelő alkalmakra is. A workshop az adott témára létrehozott munkacsoportban zajlik és tevékenysége egy adott kérdés vagy probléma interaktív elemzésére és megoldási javaslatok kidolgozására irányul többnyire kreatív technikák segítségével.

További kutatásai terveink között szerepel a Hersey-Blanchard modell másik felének is bővebb vizsgálata, mely az alkalmazottak érettségére terjed ki. Illetve az alkalmazottak körében elvégzett után későbbi célunk, hogy összehasonlítsuk az egyes alkalmazottak érettségét és az őket irányító vezetők stílusát, hogy az alkalmazott vezetési stílus mennyire felel meg a beosztottak igényeinek.

\section{Összegzés}

A vezetés a 21. században az élessé vált gazdasági válságban való versenyképesség megtartásában és megőrzésében kulcsfontosságú szerepet játszik. Ehhez hozzájárul az a tény is, hogy a vezetés nem csak alakítója, hanem része is annak a viszonynak, hogy a vevői szükségletek és a szervezet követelményei úgy kerüljenek összhangba, hogy mind a két fél elérje a céljait. Ennek a célnak az elérésében mind a vezető mind a szervezet alakul, fejlődik, és átalakul. Ezek a folyamatok teszik lehetővé a környezet változásaira való gyors reagálást, azaz a versenyképességük megőrzését.

Egy vezető sikeressége az emberekkel való bánásmódban mutatkozik meg leginkább, ugyanis a szervezetek meghatározó részei az emberek, így a szervezeti célok megvalósítása is függ tőlük. A vezetés célja, hogy összhangba kerüljenek a szervezet körülményei és az emberi szükségletek, ezáltal mindkét fél elérje a céljait.

Kutatásunkban két multinacionális vállalat esetében vizsgáltuk meg a különböző vezetési szinteken lévő vezetők vezetési stílusát. A kapott eredmények azt mutatják, hogy az alsóvezetői szinten erős feladatorientáltság jellemzi a vezetőket, míg középvezetői és felsővezetői szinten már a 
kapcsolatorientáltság felé tolódik el a hangsúly. A delegálás nagyon kevés vezetőre jellemző mindkét vállalat esetében. A részvételre épülő vezetési stílus kiemelkedik a kapott eredmények alapján, ez azt mutatja, hogy az alkalmazottak bevonása a döntéshozatalba és az egyed folyamatokba kiemelt szereppel bír mindkét általunk vizsgált vállalat esetében.

\section{Hivatkozások}

[1] Gy. Bakacsi (2004), Szervezeti magatartás és vezetés, Aula Kiadó Kft. Budapesti CORVINUS Egyetem (ISBN 963958549 1)

[2] L. Bene. (1970), A vezetés tudományos megalapozása, Közgazdasági és Jogi Könyvkiadó, Budapest.

[3] P. Dara (2011), Teljesítménymenedzsment, Budapesti Gazdasági Főiskola, Budapest.

[4] FN24 (2011) Helyzetfüggö vezetési stílusok, http://fn.hir24.hu/karrier/2007/09/28/helyzettol_fuggo_vezetesi_stilusok (letöltve: 2013.10.05 20:22)

[5] R. C. Ford, M. D. Fottler (1995), Empowerment: A matter of degree. Academy of Managerment Executive, 21-32. p.

[6] I. Gyökér (2006), Szervezeti viselkedés (oktatási segédanyag, Budapesti Mǔszaki Egyetem), Budapest

[7] J. Roóz, F. Ternovszky (2006), Az emberi erőforrás-menedzsment alapjai, Perfekt Gazdasági Tanácsadó, Oktató és Kiadó Zártkörűen Működő Részvénytársaság, Budapest. ISBN 978-963394-670-1 